\title{
PENGARUH KOMPOSISI MEDIA FILTER AIR TERHADAP PERMEABILITAS DAN CLARITAS
}

\author{
Ida Zuraida ${ }^{1}$, Wattini ${ }^{2}$, Harun Rasidi ${ }^{3}$. \\ 1,2,3 Teknik Sipil dan Perencanaan,Politeknik Negeri Pontianak, Telp. (0561) 736180 \\ Jl. Ahmad Yani Nomor 1 Pontianak, Kode Pos 78124. \\ Email: ${ }^{1}$ zuraida_lab@yahoo.co.id, ${ }^{3}$ harunrasidi100@gmail.com
}

\begin{abstract}
The results of this study can be a solution as an alternative in the provision of clean water both personal or communal through the manufacture and application of clean water filter media. Model flat rounded filter with a diameter of $5 \mathrm{~cm}$ and $1.5 \mathrm{~cm}$ high, made as many as 18 pieces. The filter media model is made with 3 variables and one variable consists of 6 types of composition comparisons ie $2: 1 ; 3: 1 ; 4: 1 ; 5: 1 ; 6: 1$ and 7: 1. The material used is filtered sand with the size of $1-1.5 \mathrm{~mm}$ diameter (escaped) and washed, another material is cement. Materials of sand and cement are evenly stirred, molded and drained (dry wind); weighing weighing in dry weight conditions and in wet weight conditions by first immersion into water for a period of time and record the temperature of the water during immersion. The dried samples were then tested using the Permeability and Clarity tool. The output of this tool in the form of water pass filter with various comparisons. The water is measured with TDSmeter and Turbidity parameters. From various comparison of filter media able to decrease TDS value equal to $2,2 \%-15,9 \%$ and Turbidity value equal to 89\% - 98\% (Variabel A).
\end{abstract}

Key words : The Filter Media, Permeability, Clarity.

\begin{abstract}
ABSTRAK
Hasil penelitian ini dapat menjadi solusi sebagai alternatif lain dalam penyediaan air bersih secara personal maupun komunity melalui pembuatan dan penerapan media filter air bersih. Model filter berbentuk bulat pipih dengan diameter $6 \mathrm{~cm}$ dan tinggi 1,5 cm, dibuat sebanyak 18 buah. Model Media filter dibuat dengan 3 variabel dan satu variabel terdiri 6 jenis perbandingan komposisi yaitu 2:1; 3:1; 4:1; 5:1; 6:1 dan 7:1. Bahan yang digunakan yaitu pasir yang disaring dengan ukuran diameter $1-1,5 \mathrm{~mm}$ (lolos) dan dicuci, bahan lain yaitu semen (Holcin). Bahan berupa pasir dan semen diaduk secara merata, dicetak dan dikeringan (kering angin); dilakukan penimbangan berat dalam kondisi berat kering dan dalam kondisi berat basah melalui perendaman terlebih dahulu kedalam air dengan jangka waktu tertentu dan mencatat suhu airnya saat perendaman. Sampel yang sudah kering kemudian dilakukan pengujian menggunakan alat Permeability and Clarity. Output dari alat ini berupa air lolos filter dengan berbagai perbandingan. Air tampungan diukur dengan parameter TDSmeter dan Turbidity. Dari berbagai perbandingan media filter tersebut mampu menurunkan nilai TDS sebesar 2,2\% - 15,9\% dan nilai Turbidity sebesar $89 \%$ - 98\% (Variabel A).
\end{abstract}

Katakunsi : Media Filter, Permeabilitas, Claritas.

\section{PENDAHULUAN}

Air bersih merupakan kebutuhan vital yang harus terpenuhi terutama bagi kelangsungan hidup manusia. Penyediaan air bersih oleh pemerintah melalui Perusahaan Daerah Air Minum (PDAM) mempunyai keterbatasan sehingga tidak semua daerah dapat terjangkau layanan air bersih. Oleh karena itu melalui penelitian ini dicoba dilakukan terobosan untuk dapat menemukan solusi alternatif terkait penyediaan air bersih secara mandiri maupun berkelompok.
Solusi alternatif berupa penerapan media filter air dengan berbagai perbandingan komposisi, dari komposisi tersebut diambil yang terbaik dalam kemampuan menjernihkan air baku menjadi air bersih tanpa perlu menggunakan bahan penjernih air yang biasa digunakan oleh masyarakat umum.

\section{METODA PENELITIAN}

Pembuatan model filter

Rancangan model filter berbentuk bulat pipih dengan cetakan dari bahan pipa PVC 
2” dengan tinggi $1,5 \mathrm{~cm}$, dibuat sebanyak 18 buah. Model Media filter dibuat dengan 3 variabel dan satu variabel terdiri 6 jenis perbandingan komposisi yaitu 2:1; 3:1; 4:1; 5:1; 6:1 dan7:1.

Selanjutnya membuat saringan untuk menyaring bahan pasir. Saringan yang dibuat yaitu dengan ukuran diameter 1 1,5 mm (lolos). Berikutnya menyiapkan bahan pasir dan semen (Holcin), dan melakukan pengayakan/penyaringan pasir, pencucian dan pengeringan bahan pasir secara alamiah. Kemudianbahan berupa pasir dan semen diaduk secara merata, dicetak dan dikeringan (kering angin); dilakukan penimbangan berat dalam kondisi berat kering dan dalam kondisi berat basah melalui perendaman terlebih dahulu kedalam air dengan jangka waktu tertentu dan mencatat suhu airnya saat perendaman.

\section{Pembuatan model alat Permeability and Clarity}

Kegiatan pembuatan model alat Permeability and Clarity yaitu mulai dari membuat rancangan, menyiapkan bahan yang diperlukan berupa pipa PVC dengan berbagai diameter, selang, sambungan PVC, sambungan kuningan, Stopkran, klem pipa, gelas tampungan, mistar, lem pipa, seal tape dan lain-lain. Kemudian mengukur, memotong, mengamplas, mencuci dan membersihkan dari kotoran yang melekat dan memasang/merakit dan mengelem pipa yang sudah dipotong. Kemudian dilanjutkan dengan ujicoba kinerja hasil rakitan, testing dengan media filter yang sudah kering, dan melakukan evaluasi terhadap hasil testing.

\section{Uji coba Model Permeability and Clarity}

Kegiatan uji coba model alat meliputi penyiapan air baku, memasukkan air baku kedalam reservoir air baku sesuai dengan kapasitasnya (4,5 liter), membuka stopkran dan mengatur debit air yang sesuai sampai mengalir ke level muka air maksimum pada reservoir distribusi atau leveling pada mulut selang distribusi ke system filter, matikan stopkran, siapkan stopwatch, kemudian buka stopkran sampai air mengalir ke system filter. Lakukan penampungn air yang melewati filter dengan waktu tertentu (catat volume air per waktu).

\section{Percobaan Permeability and Clarity}

Kegiatan Percobaan yaitu melakukan pengujian dengan penerapan semua media filter dengan berbagai perbandingan komposisi. Yang pertama dilakukan yaitu memasang media filter air (6 model perbandingan komposisi) pada system filter dengan melapisi keliling lingkaran media filter dengan isolatif (seal tape) untuk antisipasi terhadap kebocoran. Selanjutnya memasukkan air baku pada reservoir air baku dan membuka stopkran sampai air mengalir pada level maksimum reservoir distribusi dengan kapasitas 4.5 liter, pada mulut selang distribusi ke system fiter, tutup stopkran dan tambah lagi air baku pada reservoir air baku sampai penuh, kemudian buka kembali stopkran untuk memulai percobaan dan pengukuran.

Berikutnya yaitu melakukan pengukuran debit air yang tertampung pada gelas tampungan $\left(\mathrm{cm}^{3}\right)$ dalam satuan waktu (detik). Air yang tertampung diukur dengan parameter TDSmeter (kejernihan) dan Turbiditymeter (kekeruhan).

\section{Kesimpulan awal}

Dari data yang diuji dengan alat Permeability and Clarity, diambil suatu kesimpulan berdasarkan hasil pengukuran dengan parameter Permeability, Kejernihan (TDSmeter), Kekeruhan (Turbiditymeter) dengan model media filter secara keseluruhan dengan mengambil parameter yang terbaik yang dapat diterapkan oleh masyarakat.

\section{Lokasi Penelitian}

Penelitian yang dimaksud dilakukan di Laboratorium Teknik Sipil dan Perencanaan, Politeknik Negeri Pontianak (POLNEP). 


\section{Peubah Yang Diamati/Diukur}

Ketersediaan air bersih (PDAM) setempat masih bersifat terbatas. Tidak semua wilayah terjangkau oleh air bersih.

Pengamatan terhadap model media filter dan model Permeability and Clarity untuk mengetahui tingkat fungsionalitas dari rancangan alat dan media filter.

Pengukuran berat media filter, pengukuran kecepatan permeabilitas, pengukuran nilai kejernihan (TDSmeter) dan pengukuran nilai kekeruhan (Turbiditymeter).

Pengukuran tingkat kemampuan menurunkan nilai kandungan mineral dari air baku yang melalui media filter dengan berbagai perbandingan komposisi, pengukuran tingkat kemampuan menurunkan nilai kekeruhan dari air baku melalui media filter dengan berbagai perbandingan komposisi dan pengukuran kemampuan air melewati media filter dengan berbagai variasi perbandingan komposisi bahan media filter.

\section{Model Yang Digunakan}

Model yang digunakan terdiri dari :

1. Model media filter berbentuk bulat tabung dengan mal dari bahan pipa PVC diameter 2" dengan tebal 1,5 cm. Dari mal ini diisi dengan bahan media filter campuran dari berbagai variasi perbandingan.

2. Model alat Permeability and Clarity dengan bahan dasar dari pipa PVC dengan berbagai diameter sesuai dengan kebutuhan. Model ini terbagi atas beberapa elemen yaitu Reservoir air baku, Reservoir Disribusi, System distribusi, System Media Filter dan wadah tampungan air.

\section{Rancangan Penelitian}

Rancangan Permeability and Clarity dibuat untuk mengukur sampel media filter 6 buah sekaligus dengan start waktu yang sama dengan variabel komposisi yang berbeda-beda. Disini media filter yang digunakan dengan komposisi bahan Pasir dan Semen.
Sampel media filter yang dirancang mulai perbandingan 2:1 - 7:1, dibuat tiga variasi (Variabel A, Variabel B dan Variabel C), masing-masing dengan dimensi yang sama yaitu diameter 6 (termasuk mal) dan tinggi rata-rata $1,5 \mathrm{~cm}$. Nanti ke semua sampel diuji dengan alat Permeability and Clarity (Gambar 1).Pengujian dilakukan dengan 6 buah sampel sekaligus dengan perbandingan komposisi yang berbedabeda.

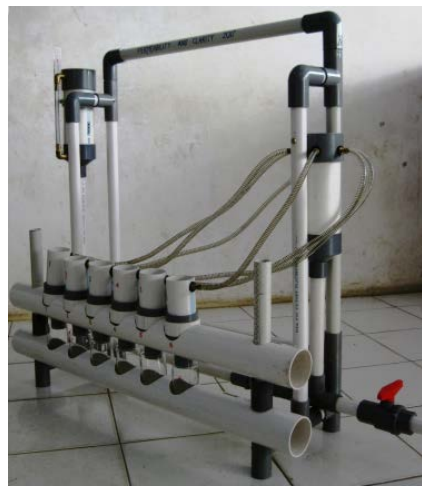

Gambar 1. Rancangan model Permeability and Clarity

Hasil pengujian berupa air yang tertampung pada wadah penampungan dari Permeability and Clarity. Air tampungan ini nanti diukur nilai TDS dan nilai Turbiditynya. Kemudian dilakukan perbandingan nilai antara nila air baku dan nilai air output dari media filter dari kedua parameter tersebut. Dan juga dilakukan perbandingan hasil dari air output media filter terhadap hasil berbagai perbandingan komposisi media filter.

Dari keseluruhan data diambil suatu kesimpulan media filter yang mana yang tepat untuk bisa diterapkan oleh masyarakat baik secara personal maupun komunity.

Teknik Pengumpulan Dan Analisa Data Data yang dikumpulkan terdiri dari tiga variabel yaitu data kecepatan permeabilitas yang diambil melalui pengukuran volume air yang tertampung dari alat Permeability and Clarity. Selanjutnya variabel kedua dan ketiga diambil melalui pengukuran sampel air dengan parameter kejernihan dan 
kekeruhan. Data kejernihan diambil melalui output dari alat TDSmeter, sedangkan data kekeruhan diambil melalui output dari alat Turbiditymeter.

Data-data diatas dikumpulkan kemudian dianalisa seberapa besar pengaruh dari berbagai variasi perbandingan media filter mampu untuk menaikkan nilai kejernihan dan menurunkan nilai kekeruhan dari air baku.

\section{HASIL DAN PEMBAHASAN \\ Berat Kering}

Berat kering merupakan berat media filter dengan diameter $6 \mathrm{~cm}$ dan tinggi $1,5 \mathrm{~cm}$ dalam kondisi kering angin. Pada Gambar2 ditampilkan bentuk grafik hampir linier yaitu cenderung berat semakin menurun mengarah ke perbandingan $7: 1$, ini masuk dalam kategori wajar karena perbandingan 7:1 menggunakan komposisi pasir 7 berbanding semen 1, lebih banyak rongga. Dari Gambar2 juga tampak ada media filter yang dengan berat yang mencolok, tapi nanti bisa dilihat pengaruhnya terhadap hasil pengukuran dengan parameter yang lain.

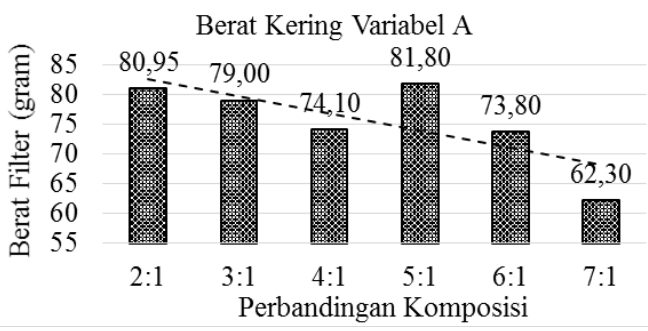

Gambar 2. Berat Kering Media Filter Variabel

A

Pada Gambar 3 terlihat pola grafik yang tidak linier, ada dua tempat yaitu pada perbandingan 2:1 dan perbandingan 4:1.

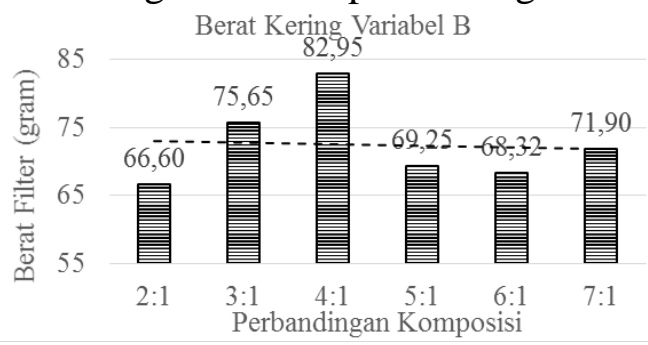

Gambar 3. Berat Kering Media Filter Variabel
Pada Gambar 4 terdapat data yang mencolok yaitu pada posisi perbandingan 2:1, 4:1 dan 6:1

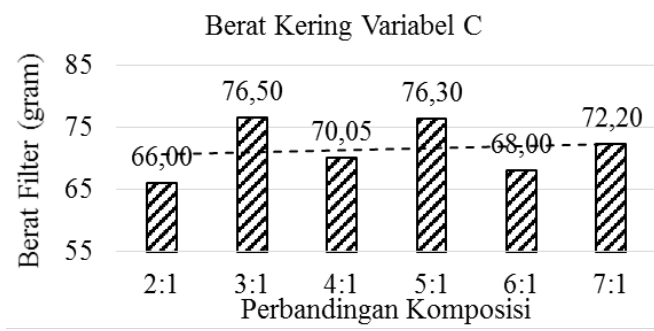

Gambar 4. Berat Kering Media Filter Variabel C

\section{Berat Basah}

Berat basah yaitu berat kering media filter ditambah berat Air Pori, yang didapat dengan cara media filter direndam dengan lama waktu tertentu kemudian ditimbang. Dari berat basah ini (Gambar 5) secara keseluruhan perbandingan dianggap normal tapi masih ada satu yang tidak normal yaitu pada perbandingan 5:1, sama juga dengan berat dalam kondisi kering pada Gambar 2, pada posisi ini juga memiliki berat yang mecolok jika dilihat secara linier.

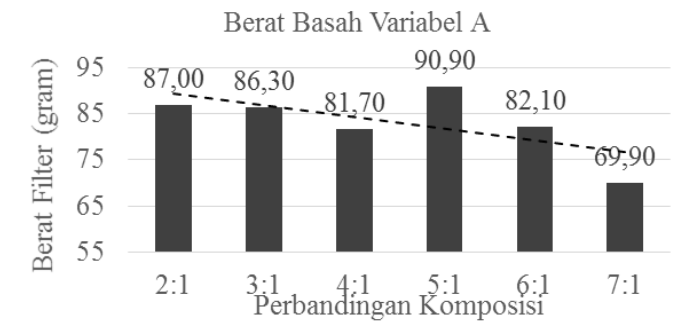

Gambar 5. Berat Basah Media Filter Variabel

A

Demikian juga halnya dengan Berat Basah pada Gambar 6 juga menunjukkan berat yang tidak linier, polanya sama dengan Gambar 3.

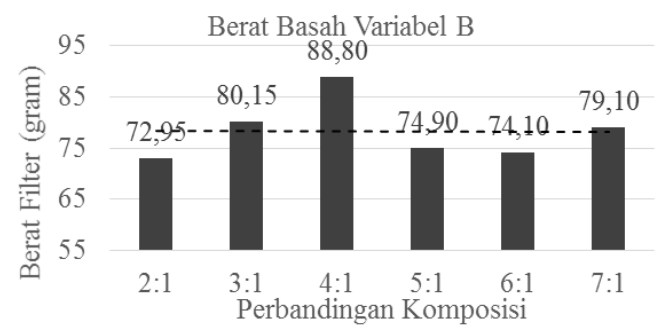

Gambar 6. Berat Basah Media Filter Variabel

B 
Pada Gambar 7 juga menunjukkan grafik yang tidak linier, sama halnya dengan berat kering variabel C (Gambar 4).

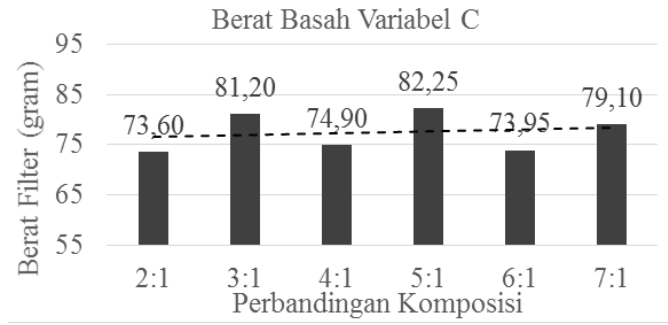

Gambar 7. Berat Basah Media Filter Variabel

$\mathrm{C}$

\section{Prosentase Air Pori}

Air pori didapat dari selisih antara berat kering dan berat basah dari media filter, kemudian diambil besaran prosentase air pori terhadap berat total atau berat basah media filter. Cara analisanya yaitu semakin besar nilai prosentasi air pori maka ronga pori juga akan besar. Jika rongga pori besar maka akan mempengaruhi kecepatan permeabilitas atau debit air yang tertampung akan lebih besar dan ini juga akan empengaruhi nilai kejernihan (TDS) dan nilai kekeruhan (Turbidity).

Berikut Gambar 8, grafik prosentase air pori dari berbagai perbandingan. Pola grafik menunjukkan nilai angka yang normal yaitu semakin besar angka perbandingannya maka nilai air pori juga besar. Yang terendah yaitu 7\% terdapat pada perbandingan 2:1 dan yang terendah pada posisi perbandingan 7:1 dengan besaran 10,9\% dari berat total.

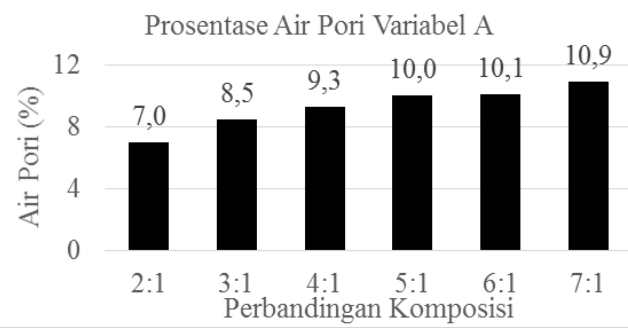

Gambar 8. Prosentase Air Pori Terhadap Berat Total (Variabel A)

Pada Gambar 9 (Variabel B) masih tergolong normal, linear dengan nilai terendah pada posisi perbanding 3:1 dengan nilai 5,6\% dan yang tertinggi 9,1\% pada posisi perbandingan 7:1, niai yang tidak normal yaitu pada perbandingan 2:1 dengan nilai $8,7 \%$.

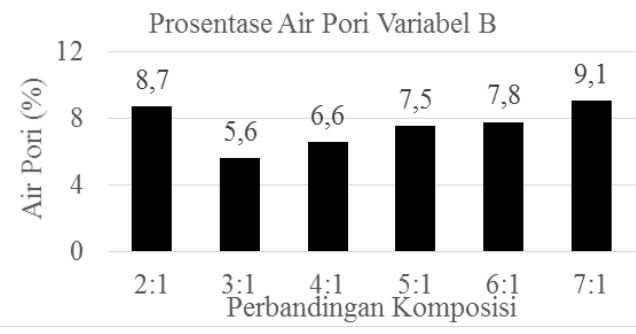

Gambar 9. Prosentase Air Pori Terhadap Berat Total (Variabel B)

Selanjutnya pada Variabel C (Gambar 10), pola grafiknya sama dengan pada Gambar 9 yaitu hampir linear antara nilai terendah 5,8\% dan tertinggi $8,7 \%$ pada posisi 3:1 dan 7:1 serta juga memiliki nilai yang tidak normal yaitu pada posisi perbanding 2:1 dengan nilai 10,3\%.

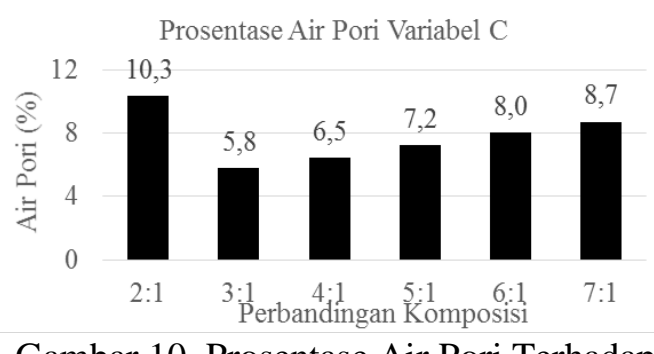

Gambar 10. Prosentase Air Pori Terhadap Berat Total (Variabel C)

\section{Permeabilitas}

Permeabilitas yaitu kemampuan air menembus media filter, dalam hal ini yang dicari adalah kecepatan menembus/merembes melewati media filter (va) $=\mathrm{Q} / \mathrm{A}$. Debit $(\mathrm{Q})$ didapat dari volume air tertampung pada alat Pernmeability and Clarity, sedangkan A adalah luas dari muka media filter. Dari data kecepatan ini dapat diketahui jumlah air yang dihasilkan dalam waktu tertentu dan ini dijadikan dasar dalam perencanaan bak penampungan.

Dari Gambar 11 (Variabel A) terlihat bahwa kemampuan merembes terendah terletak pada perbandingan 3:1 dengan nilai $0,0002 \mathrm{~cm} /$ det, tertinggi pada posisi perbandingan 5:1 dengan nilai 0,0014 $\mathrm{cm} /$ det, itu merupakan nilai rata-rata terendah. Sedangkan nilai rata-rata 
teringgi yaitu pada posisi perbandingan 6:1 dengan nilai $0,0095 \mathrm{~cm} /$ det dan tertinggi pada perbandingan 7:1 dengan nilai kecepatan (va) $=0,0142 \mathrm{~cm} /$ det.

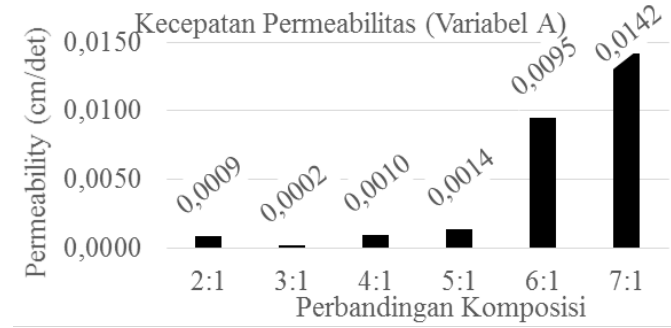

Gambar 11. Permeabilitas Terhadap Media Filter (Variabel A)

Berikutnya Gambar 12 (Variabel B) nilai rata-rata terendah yaitu pada posisi perbandingan 2:1 - 6:1 dengan nilai antara $0,0001-0,0012 \mathrm{~cm} /$ det. Sedangkan nilai kecepatan (va) tertinggi terletak pada perbandingan 7:1 dengan nilai 0,0700 $\mathrm{cm} /$ det.

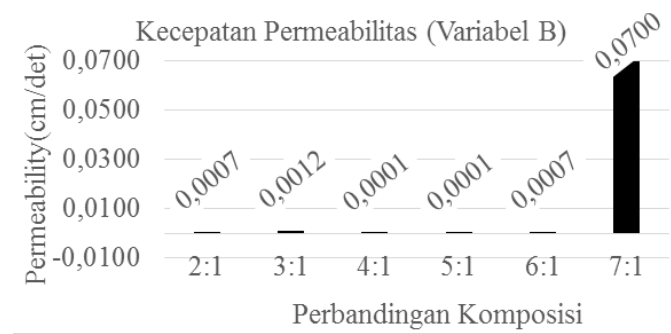

Gambar 12. Permeabilitas Terhadap Media Filter (Variabel B)

Selanjutnya pada Gambar 13 (Varabel C), nilai kecepatan rembesan rata-rata terendah yaitu 4:1 sampai dengan perbandingan 7:1 dengan nilai terkecil yaitu $0,0004 \mathrm{~cm} /$ det dan tertinggi 0,0054 $\mathrm{cm} /$ det. Nilai tertinggi dengan nilai yang mecolok yaitu sebesar $0,0483 \mathrm{~cm} /$ det pada posisi perbandingan 2:1. Dan satu lagi pada Variabel $\mathrm{C}$ ini terdapat data dengan nilai nol ini mengindikasikan bahwah pada perbandingan ini terdapat kekosongan data air, artinya air baku tidak bisa menembus media filter.

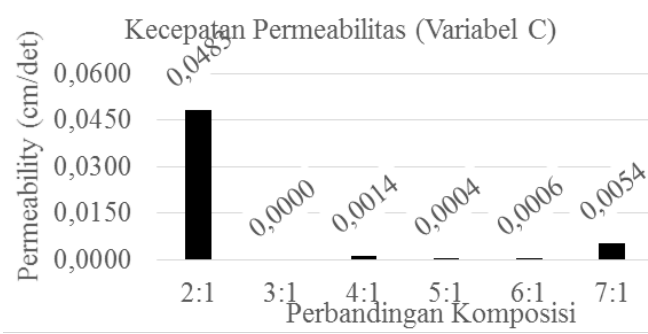

Gambar 13. Permeabilitas Terhadap Media Filter (Variabel C)

\section{Kejernihan}

Kejernihan adalah salah satu parameter yang dijadikan sebagai barometeruntuk mengetahui air yang disaring jernih atau tidak. Untuk mengukur kejernihan air digunakan alat dengan nama TDSmeter dengan satuan $\mathrm{mg} / \mathrm{liter}$ atau part per million (ppm). Setelah air baku diukur TDSnya dengan nilai 453 ppm setelah itu baru dilakukan pengukuran nilai TDS dari air yang lolos media filter. Pada Gambar 14 (Variabel A) terlihat bahwa nilai TDS dibawah nilai air baku yaitu yang terendah dengan nilai 381 ppm pada posisi perbandingan 5:1 dan yang tertinggi 443 ppm pada posisi perbandingan 2:1.

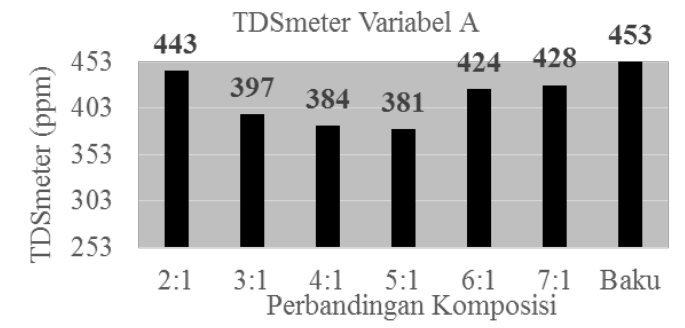

Gambar 14. Besaran Nilai TDS Variabel A

Tetapi pada Gambar 15 terdapat nilai TDS sama dengan nilai air baku yaitu dengan nilai 356 ppm pada posisi perbandingan $7: 1$, ini menandakan bahwa pada perbandingan 7:1 mengindikasikan bahwa nilai kecepatan permeabilitas juga mempengaruhi nilai TDS (lihat Gambar 12). Nilai yang terendah pada Variabel ini yaitu pada posisi perbandingan 6:1 dengan nilai 282 ppm dan nilai yang tertinggi terletak pada posisi perbandingan 5:1 dengan nilai 345 ppm. 


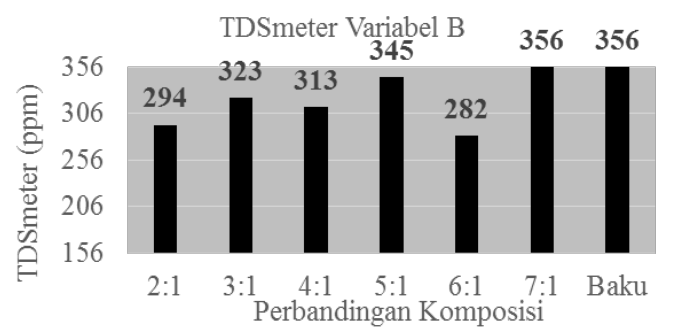

Gambar 15. Besaran Nilai TDS Variabel B

Pada Variabel C (Gambar 16) terdapat data kosong, artinya debit air dari Permeability tidak ada jadi tidak bisa diukur (0). Pada gambar tersebut terlihat bahwa TDS terukur masih dibawah nilai TDS air baku dengan nilai 397 ppm. Pada gambar tersebut terlihat nilai terendah terletak pada posisi perbandingan 7:1 dengan nilai 304 ppm dan tertinggi sebesar 373 ppm pada posisi perbandingan 4:1.

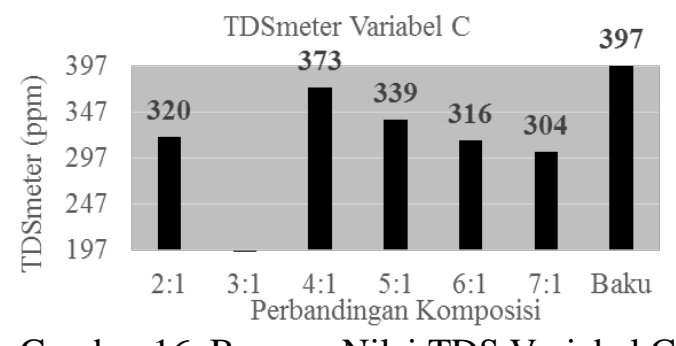

Gambar 16. Besaran Nilai TDS Variabel C

\section{Prosentase Penurunan Nilai TDS}

Kemampuan media filter menurunkan nilai TDS terlihat pada Gambar 17 (Variabel A). Pada gambar tersebut terdapat nilai prosentase yang terbesar kemampuan menurunkan nilai TDS terukur dari air baku yaitu 12,4\%, 15,2\% dan $15,9 \%$ pada posisi perbandingan $3: 1$, 4:1 dan 5:1. Selanjutnya nilai terendah yang lain yaitu sebesar 2,2\%, 6,4\% dan 5,5\% pada posisi perbandingan 2:1, 6:1 dan 7:1. Jadi secara keseluruhan kemampuan media filter air menurunkan nilai TDS yaitu antara 2,2\% - 15,9\%

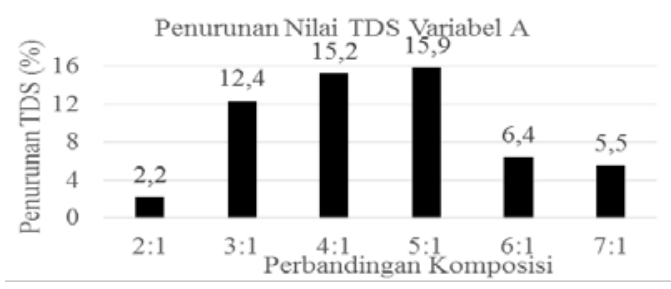

Gambar 17. Prosentase Tingkat Penurunan Nilai TDS (Variabel A)
Pada Variabel B, Gambar 18 terdapat nilai nol (0) pada posisi perbandingan 7:1, ini menggambarkan bahwa pada posisi ini nilai TDS air bakunya sama dengan nilai TDS pada posisi perbandingan 7:1 (lihat Gambar 15). Pada Variabel ini prosentase tingkat penurunan nilai TDS bervariasi, tidak linear yang terendah pada posisi 5:1 dengan nilai $3,1 \%$ dan tertinggi pada posisi perbandingan 6:1 dengan nilai 20,8\%. Jadi pada variabel ini kemampuan media filter menurunkan nilai TDS antara $3,1-20,8 \%$.

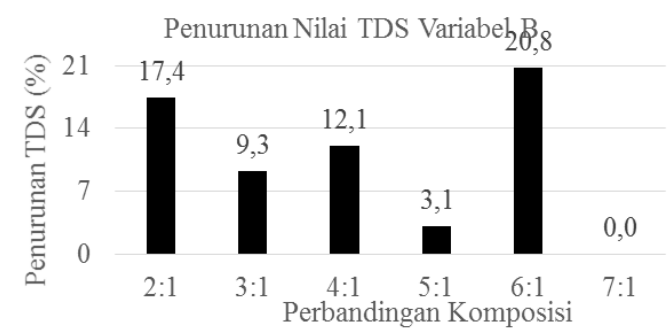

Gambar 18. Prosentase Tingkat Penurunan Nilai TDS (Variabel B)

Berikut pada Variabel C (Gambar 19) terdapat data dengan nilai nol (0), ini menandakan pada posisi perbandingan tersebut volume air tidak terukur (Gambar 16). Nilai TDS yang terendah pada Variabel C ini yaitu 6\% pada posisi perbandingan $4: 1$ dan tertinggi $23,4 \%$ pada posisi perbandingan 7:1.

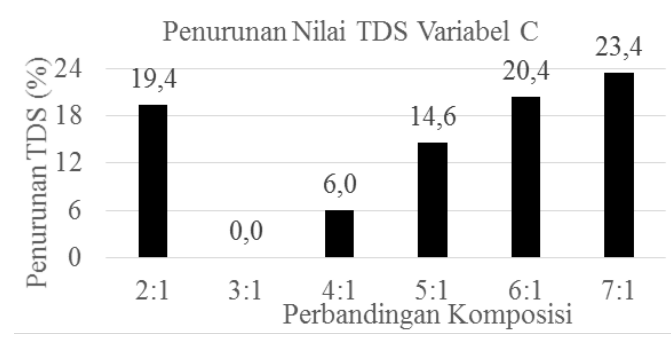

Gambar 19. Prosentase Tingkat Penurunan Nilai TDS (Variabel C)

\section{Kekeruhan}

Kekeruhan (Turbidity) merupakan barometer kedua setelah kejernihan (TDS), semakin rendah nilai Turbidity maka semakin baik artinya air akan semakin jernih. Nilai kekeruhan diambil dengan menggunakan alat dengan 
namaTurbiditymeter dalam satuan Nephelometric Turbidity Unit (NTU). Nilai Turbidity terukur dibandingkan dengan nilai Turbidity dari air baku. Berikut ditampilkan nilai Turbidity dari masing-masing perbandingan dengan tiga variasi sampel.

Pada Gambar 20, pada Variabel A terlihat bahwa nilai ait baku terukur sebesar 175 NTU jika dibandingkan dengan nilai dengan perbandingan 2:1 sampai 7:1 terlihat jenjangnya sangat jauh ini menandakan kemampuan media filter untuk menyaring air dianggap berhasil. Dari gambar tersebut terlihat nilai Turbidity terendah yaitu terletak pada posisi perbandingan 3:1 dengan nilai 3,55 NTU dan tertinggi pada posisi perbandingan 2:1 dengan nilai 20 NTU.

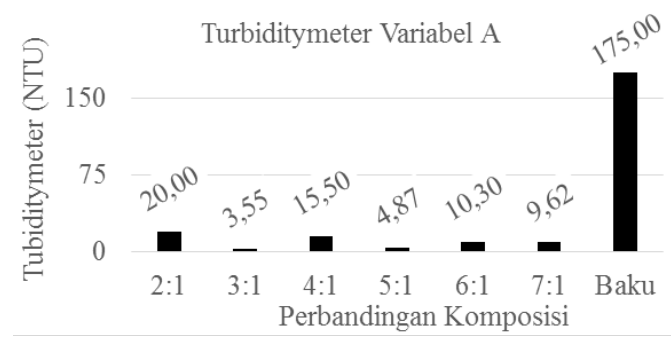

Gambar 20. Besaran Nilai Turbidity (Variabel A)

Begitu juga pada Variabel B (Gambar 21) juga mampu menurunkan nilai Turbidity sebesar terendah dengan nilai 8 NTU pada posisi perbandingan 3:1 dan teringgi dengan nilai 89 NTU pada posisi perbandingan 2:1, dibandingkan dengan nilai air baku sebesar 138 NTU terhitung berhasil menurunkan nilai asalnya.

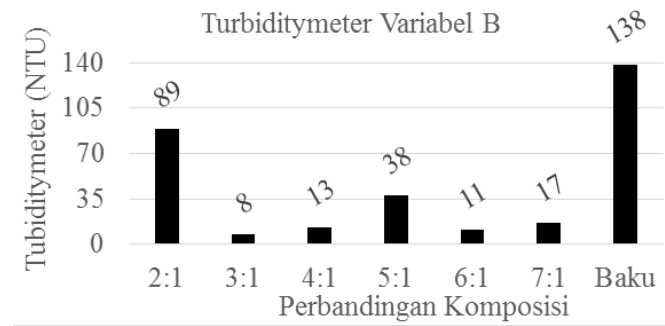

Gambar 21. Besaran Nilai Turbidity (Variabel B)

Berikut pada Variabel C (Gambar 22) menunjukkan besaran nilai Turbidity yang dapat diturunkan dari air baku dengan nilai 226 NTU dengan rincian yang terendah dengan nilai 32,4 NTU pada posisi 5:1 dan tertinggi dengan nilai 56,8 NTU. Pada Variabel ini terdapat data kosong (0) pada posisi perbandingan 3:1, ini merupakan kekosongan air yang tembus media filter, . Pada Variabel ini juga terdapat data error pada perbandingan 2:1. Dikatakan data error karena data Turbidity terukur (335 NTU) melebihi nilai air baku sebesar 226 NTU. Jadi data Error ini tidak digunakan bisa jadi terkontaminasi dengan mineral yang lain.

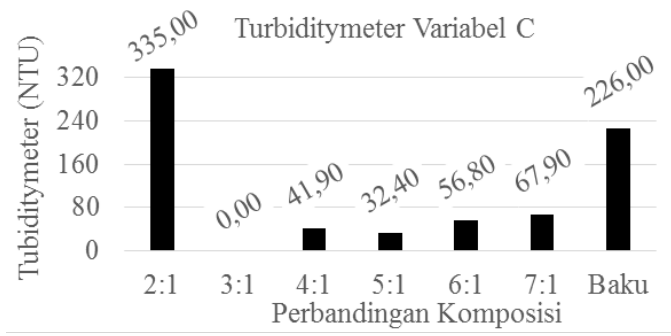

Gambar 22. Besaran Nilai Turbidity (Variabel C)

\section{Prosentase Penurunan Nilai Turbidity}

Tingkat penurunan nilai kekeruhan yaitu besaran prosentasi dari media filter menurunkan nilai Turbidity dari air baku. Kalau dilihat pada Gambar 23 (Variabel A) terlihat bahwa kemampuan media filter menurunkan nilai kekeruhan (Turbidity) sangat besar yaitu antara yang terendah sebesar $89 \%$ pada posisi perbandingan 2:1 dan yang tertinggi sebesar $98 \%$ pada posisi perbandingan 3:1. Pada Variabel A ini prosentase kemampuan menurunkan nilai Turbidity termasuk rata-rata yang terbesar dibanding pada variabel yang lain (Variabel B dan Variabel C).

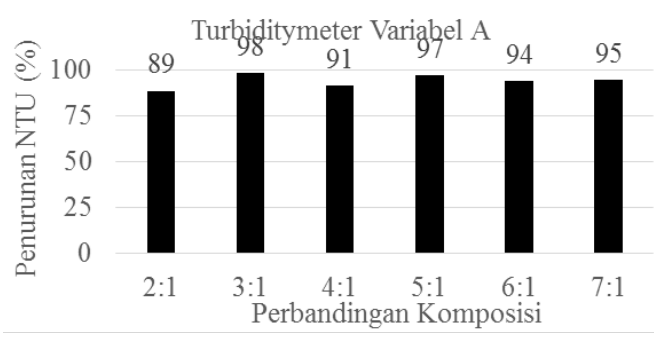

Gambar 23. Prosentase Tingkat Penurunan Nilai Turbidity (Variabel A) 
Pada variabel B (Gambar 24) menunjukana nilai terendah sebesar $36 \%$ pada posisi perbandingan 2:1 dan terendah 94\% pada posisi perbandingan 3:1

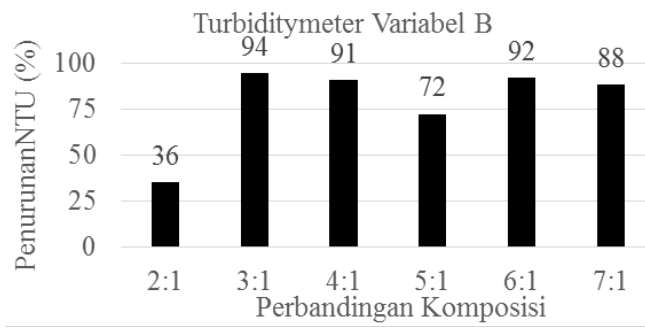

Gambar 24. Prosentase Tingkat Penurunan Nilai Turbidity (Variabel B)

Pada Variabel C (Gambar 25) juga demikian nilai terendah $70 \%$ pada posisi perbandingan 7:1 dan tertinggi 86\% pada posisi perbandingan 5:1. Pada Variabel ini juga terdapat data kosong dan dikosongkan, ini merupakan data Error dan 0 data, sama halnya juga dengan parameter yang lain yang sudah dibahas sebelumnya pada variabel C terkait dengan data kosong.

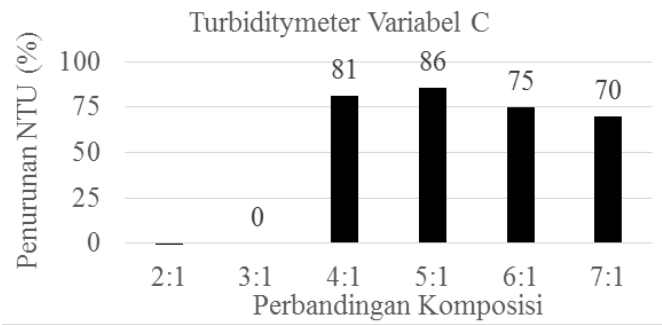

Gambar 25. Prosentase Tingkat Penurunan Nilai Turbidity (Variabel C)

Dari hasil pengukuran dengan parameter berat kering, berat basah, prosentase Air Pori, kejernihan air (TDS), prosentase penurunan nilai TDS, kekeruhan air (Turbidity) dan prosentasi penurunan nilai Turbidity. Semua parameter mepengaruhi parameter yang lain. Nilai prosentasi air pori mempengaruhi kecepatan permeabilitas (va) semakin besar nilai prosentase air pori akan mempercepat rembesan, semakin besar nilai kecepatan rembesan (va) akan semakin kecil nilai prosentase kemampuan menurunkan nilai kejernihan (TDS) dan juga akan semakin kecil nilai prosentase kemampuan menurunkan nilai kekeruhan (Turbidity).
Dari ketiga variabel percobaan media filter (Variabel A, Variabel B dan Variabel C) yang terbaik yaitu data pada Variabel A karena pada variabel ini menunjukkan grafik yang wajar.

Pada Variabel B dan Variabel C terdapat data yang disortir (Error) dengan alasan yaitu :

1. Pada Gambar 12 (Variabel B), pada perbandingan $7: 1$ nilai

Permeabilitasnya (va) sebesar 0,0700 $\mathrm{cm} /$ det, ini tergolong mencolok, dan terbukti pada Gambar 15 dengan nilai TDSnya mencapai nilai sama dengan nilai TDS air baku dengan nilai 356 ppm, tidak hanya itu bisa dibuktikan dengan nilai prosentasi kemampuan menurunkan nilai TDSnya sebesar nol (0), lihat Gambar 19. Jadi data tersebut dianggap Error dan tidak bisa dipakai.

2. Pada Gambar 22 (Variabel C), pada perbandingan 2:1, pada nilai Turbidity sebesar 335 NTU padahal nilai air baku hanya 226 NTU, ini juga bisa dibuktikan dengan nilai kemampuan menurunkan nilai Turbidity sebesar 48 (Gambar 24). Jadi dengan nilai 335 NTU termasuk mustahi (Error).

3. Pada Gambar 13 (Variabel C), pada perbandingan3:1,nilai

Permeabilitasnyasama dengan nol atau terdapat kekosongan data ini maksudnya adalah air baku tidak mampu menembus media filter sehingga airnya tidak ada. Buktinya pada nilai TDS (Gambar 16) dengan data kosong, serta nilai Prosentase Penurunan nilai TDS (Gambar 19) pada perbandingan 3:1 terdapat data kosong, Nilai Turbidity (Gambar 22) dan Prosentase penurunan nilai Turbidity (Gambar 25) juga tercatat tanpa data.

Selanjutnya dicoba untuk melakukan penggabungan untuk diambil nilai ratarata dari beberapa parameter pengukuran, dalam hal ini data Error tidak dimasukkan. Dari Gambar 26, menunjukkan kemampuan rata-rata media filter dalam 
fungsi menurunkan nilai Total Dissolved Solids (TDSmeter) dan Turbiditymeter dalam hal ini meningkatkan kapasitas Claritas. Dengan uraian prosentase air pori dengan nilai antara 6,63\% dari berat total sampai dengan 9,57\%, menurunkan nilai TDS sebesar antara $10,85 \%$ sampai dengan $15,87 \%$ dan juga dapat menurunkan nilai Turbiditas antara 62,5\% sampai dengan $96 \%$.

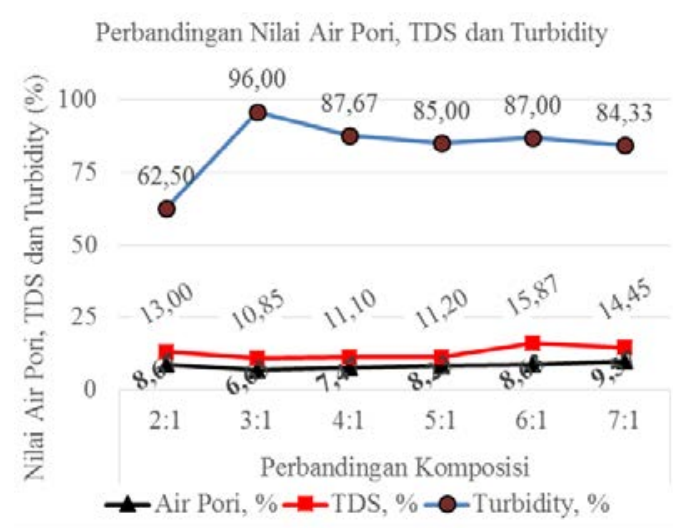

Gambar 26. Prosentasi Pembanding Antara Air Pori, TDS dan Turbidity (Rata-rata Gabungan)

\section{KESIMPULAN}

Jadi kesimpulannya bahwa media filter yang dibuat dari bahan campuran pasir dan semen dengan komposisi yang berbeda-beda dapat digunakan sebagai media filter air bersih. Media Filter ini dipilih yang terbaik sesuai dengan perbandingan komposisi yang cocok untuk diterapkan dimasyarakat.

Dengan diterapkannya media filter air ini oleh masyarakat maka secara otomatis akan meringankan beban Pemerintah dalam hal penyediaan layanan air bersih bagi masyarakat terutama masyarakat daerah terpencil.

Hasil penelitian ini masih bersifat permulaan, masih bisa dikembangkan melalui penerapan standar pembuatan media filter lanjutan.

Walaupun hasil penelitian hanya mampu menurunkan nilai kekeruhan (Turbidity) sebesar 62,5 - 96\% secara maksimal namun ini cukup untuk bisa mengurangi bahan Tawas atau PAC sebagai bahan untuk menjernihkan air.

\section{UCAPAN TERIMA KASIH}

Terima kasih kami ucapkan kepada Lembaga Penelitian dan Pengabdian Pada Masyaraka (PPM) Politeknik Negeri Pontianak yang telah memberikan support finansial dalam kegiatan penelitian ini.

\section{DAFTAR PUSTAKA}

[1] Djoko, Sarwono. 2007. "Pengukuran Sifat Permeabilitas Campuran Porous Asphalt”. Surakarta. Media Teknik Sipil..

[2] Ika Nuzula, Nike dan Endarko. 2013. "Perancangan dan Pembuatan Alat Ukur Berbasis Microkontroler ATMega8535”. Jurnal Sains dan Seni Pomits, Vol.2 No.1. Surabaya.

[3] Kautsar, Muhammad, dkk.. 2015. "Sistem Monitoring Digital Penggunaan dan Kualitas Kekeruhan Air PDAM Berbasis MicrokontrolerATMega328

Menggunakan Sensor Aliran Air dan Sensor Fotodiode”. Journal Teknologi dan Sistem Komputer, Vol.3, No. 1, (e-ISSN:2338-0403). Semarang.

[4] Rachmansyah, Fajri, dkk.. 2014. "Perancangan Dan Penerapan Alat Ukur Kekeruhan AirMenggunakan Metode Nephelometrik Pada InstalasiPengolahan Air Dengan Multi Media Card (MMC) Sebagai MediaPenyimpanan (Studi Kasus Di PDAM Jember)”. Jember. Berkala Sainstek, 